Canadian Journal of Higher Education Revue canadienne d'enseignement supérieur

Volume 49, No. 1, 2019, pages 22 - 46

\title{
Pluralizing Frameworks for Global Ethics in the Internationalization of Higher Education in Canada
}

\author{
Sharon Stein \\ University of British Columbia \\ Vanessa de Oliveira Andreotti \\ University of British Columbia \\ Rene Suša \\ University of British Columbia
}

\begin{abstract}
Internationalization continues to be a priority within many Canadian universities. While it is imperative to attend to the ethical dilemmas that accompany the intensification of internationalization, different ethical frameworks operate according to different orientating assumptions. In this paper, we seek to pluralize and deepen conversations about the ethics of internationalization by illustrating how three global ethics approaches address questions of international student mobility, study and service abroad, and internationalizing the curriculum. We conclude by emphasizing the need for both scholars and practitioners to engage in multi-voiced, critically-informed analyses, and dissensual conversations about complex ethical dilemmas related to internationalization.
\end{abstract}

\begin{abstract}
Résumé
Beaucoup des universités Canadiennes donnent la priorité à l'internationalisation. Bien qu'il faut considerer les dilemmes éthiques qui suivent l'intensification de l'internationalisation, il faut dire que des divers cadres éthiques suivent des divers hypothèses fondamentales. Dans cet article, nous cherchons de diversifier et d'approfondir les conversations sur l'éthique de l'internationalisation; nous illustrons comment trois approches éthiques répondent aux questions de mobilité des étudiants internationals, des études/l'aide internationals, etl'internationalisation du programme. Nous
\end{abstract}


soulignons la neccesité pour les spécialistes et des professionels d'engager dans l'analyse critique et des plusiers voix, et d'engage dans des conversations en désaccord sur les dilemmes compliqués de l'internationalisation.

\section{Introduction}

In 2014, Universities Canada found that 95\% of Canadian universities included internationalization or global engagement in their strategic planning, and 82\% ranked internationalization as one of their top five priorities (Universities Canada, 2014). It was also in 2014 that the Canadian federal government released its first ever international education strategy, in which, among other things, it announced plans to "double the size of our international student base from 239,131 in 2011 to more than 450,00o by 2022 (without displacing Canadian students)" (Department of Foreign Affairs, Trade and Development, 2014, p. 11). Canada was by then already the seventh-most-popular host country for international students (Canadian Bureau for International Education, 2015). Nearly five years later, internationalization continues to be a central priority for Canadian institutions, and indeed for the federal and provincial governments. Meanwhile, Canada remains a desirable educational destination, with international student enrolments growing nearly $18 \%$ from 2015 to 2016 alone (ICEF, 2017), on top of an 83\% increase from 2008 to 2015 (Canadian Bureau for International Education, as cited in Garson, 2016). The majority of these international students are attending post-secondary institutions.

In the context of this rapid expansion of internationalization in Canadian institutions, in 2014 the Association of Canadian Deans of Education released the Accord on the Internationalization of Education, which delineated potential benefits of internationalization as well as potential risks and implications for practice. The Accord promoted inclusive and sustainable international mobility experiences, ethical and reciprocal research and teaching partnerships, curriculum internationalization premised on global justice, and long-term institutional commitments to internationalize. Since then, despite increasing attention to ethical issues related to internationalization, many questions and concerns around international recruitment, research, and engagement have remained unresolved. In particular, there is an ongoing tension between national, provincial, and institutional imperatives to expand internationalization for the ends of income generation and global competitiveness, and the development and implementation of internationalization practices and policies that respond to the imperatives of equity, global learning, and social accountability (Beck, 2012; Garson, 2016; Larkin, 2015). Many of the ethical concerns about internationalization that arise in Canada are relevant in other contexts, given that they are linked to long-standing uneven global relations that have contributed to the production of a Western-dominated higher education landscape.

According to Marginson (2006), "Global higher education is produced and consumed within a world-wide university hierarchy in which inequality between research universities, and between nations-and the often uni-directional flows of people, capital and knowledge associated with those inequalities-are necessary to global competition" (p. 35). This competition tends to be strongly biased in favour of institutions with high international prestige and a comparatively robust resource capacity, which are disproportionately concentrated in the Global North (Marginson \& Sawir, 2005). At the same time that higher education is increasingly framed as an important means of national competition in places like Canada (Larkin, 2015; Stein, 2018), these nation states are also investing fewer 
public monies in higher education, instead calling upon individual students to invest in their own education, as is evident in growing tuition costs and declining public funding (Fisher, Rubenson, Shanahan, \& Trottier, 2014).

In this context, some have voiced concerns that universities in Canada and elsewhere in the Global North are treating internationalization as a means of generating revenues to make up for declining public funding from local and national governments. For instance, in Canada, Usher (2018) points out that as combined government transfers (provincial and federal) to universities have steadily declined since 2009, cuts in funding have largely been filled by growing numbers of international students and their rising tuition costs (which have been growing at a rate of $4 \%$ per year). The perceived benefits of internationalization are not only direct, but also relate to the larger project of global economic and epistemological hegemony (Johnstone \& Lee, 2014). Larkin (2015) argues:

There is clearly a belief that internationalizing education will not only provide greater revenues through knowledge products and the penetration of new markets, but that it will provide Canadian universities with opportunities to recruit students and faculty from abroad (as both providers and producers of revenue) and will position national research universities to compete at the highest level globally. (p. 144)

She contends that, as a result, internationalization efforts often reproduce Canada's geopolitical hegemony, particularly in relation to partners in the Global South (see also Johnstone \& Lee, 2014). Others point out that in the rush for revenues and other international opportunities, Canadian institutions have failed to create culturally responsive environments for international students and scholars (Guo \& Guo, 2017), or to adequately consider and manage the ethical complexities of international study and service abroad experiences and research partnerships (Beck, 2012; Khoo, 2011; Larkin, 2015).

Even among scholars and practitioners of international higher education who are not critically inclined, there is thus a growing anxiety that internationalization has "lost its way" (Brandenburg \& de Wit, 2011). ${ }^{1}$ Efforts to assess and reimagine the current ethical orientation of mainstream internationalization must take into account the many competing interests, investments, values, and desires that shape its current form and seek to influence its future direction. There are multiple possible responses to emergent ethical dilemmas and their related political implications, and whichever response is chosen will likely depend on the context-specific configuration of power, policy, and desires; this makes it difficult to pose simple or static solutions. Thus, rather than prescribe "best practices" or advocate for one ethical approach in particular, in this paper we consider how liberal, critical, and decolonial approaches to global ethics would frame and respond to challenges related to three primary areas of internationalization: international student mobility, internationalizing curricula, and study and service abroad.

We begin by reviewing the three different ethical approaches identified, paying particular attention to the decolonial approach as it is the most underdeveloped within existing ethics scholarship and practice. Further, we note that while each approach offers something and each has limitations, if we are truly going to pluralize the available ethical frames for action, then the current hegemony of liberal ethics will need to be denaturalized (without dismissing its gifts); otherwise it will continue to crowd out other possibilities. Following this review of approaches, we illustrate how they might be used to deepen and complicate ethical understandings of challenges related to three areas of internation- 
alization. We conclude by emphasizing the need for scholars and practitioners to engage in multi-voiced, critically informed analyses, and dissensual conversations about complex ethical dilemmas related to internationalization.

\section{Approaches to Global Ethics}

In a contemporary era characterized by global interdependencies that range from horizontally collaborative to violently extractive, and everything in between, there is growing need for ethical frameworks that can address (unevenly) shared problems and proliferate possibilities for sustaining human (co)existence on a finite planet. Global ethics is a field of study that addresses international, institutional, and interpersonal efforts to navigate and negotiate complex dilemmas that are not bounded by local contexts or national borders. These include challenges related to access to food and clean water, migration and mobility, poverty, exploitation, resource extraction, trade policy, education, development, health and well-being, climate change, armed conflict, and human rights (Dower, 2014; Hutchings, 2010; Widdows, 2011; O’Byrne, 2017). Yet, according to Drydyk (2014), "agreement is lacking on what global ethics is: what its boundaries are, what is to be included, and what is not" (p. 16). Different approaches to global ethics operate according to different orientating assumptions, horizons of hope, and theories of change.

Rather than view this lack of consensus as a problem, in this paper we propose that learning to work with and through complexity, uncertainty, and difference is a vital element of global ethics education. Different ethical frameworks offer different diagnoses of the problems we face, and different propositions as to how we should respond. In this paper we seek to offer an opening for conversations that will prepare people to identify different ethical frameworks and to assess where they come from and what they assume, where they lead, what they enable and what they foreclose, and what the tensions, edges, and contradictions are between them. Ultimately, the idea is to prepare people to think self-reflexively about their own relationships to these and other frameworks, so that they might both understand a single issue from different perspectives and develop the courage to determine and take responsibility for their own contextual ethical choices.

Thus, instead of meeting expectations and desires for universalizing solutions, advocating for a singular ethics framework, or making recommendations about any specific change in internationalization policy and practice, we argue for deeper analyses and a cultivation of ecologies of knowledges (Santos, 2007) in educational research. For this purpose, we review three different approaches to global ethics: liberal, critical, and decolonial. These approaches hardly canvas the entire field of existing and possible frameworks, but they capture some of the more notable patterns that circulate within Canadian higher education institutions. Further, within each identified approach there are significant variations that we cannot fully capture, while at the same time there may be overlap between them. Thus, we present this paper as an initial invitation for further conversation and engagement, rather than a comprehensive map of ethical possibilities.

\section{Liberal Approaches to Global Ethics}

The liberal approach to global ethics is rooted in a global imaginary that naturalizes certain architectures of existence as if they were universal, and thereby circumscribes what appears possible and desirable to know, desire, and create (Stein, Andreotti, \& Suša, 
2016). The result of this universalism is the paradoxical projection of a particular way of knowing and being as if it were the only valid and valuable one. As with any ethical approach, there may be a range of perspectives that fall within liberal ethics, but there are parameters on the degrees of acceptable difference that may be included; anything that challenges the primary dimensions of the liberal global imaginary will likely be invalidated or invisibilized, or may even be illegible. We identify these primary dimensions as relating to the presumed political authority of nation states, economic inevitability of capitalist markets, epistemic authority of Western knowledge, and anthropocentric separation of humans from the earth (Stein, Hunt, Suša, \& Andreotti, 2017). Within the liberal global imaginary, ethical problems are not only articulated within these "universal" frames, it is also presumed that solutions to these problems can be found within them. In other words, the orienting liberal assumptions are that more social order and civil rights within the bounds of the nation state, more economic access to social mobility within the bounds of capitalism, and more shared knowledge within the bounds of Western epistemic traditions will enable us to solve ethical problems.

Despite the hegemony of this liberal ethical approach, some have problematized its organizing assumptions, suggesting that it narrows possibilities for relationality across difference (Donald, 2012; Gaztambide-Fernández, 2012; Kuokkanen, 2008); denies marginalized communities resources and opportunities to create and lead their own visions for education, development, and change (Battiste, 2013; Gandhi, 2011; Kapoor, 2014; McEwan, 2008; Spivak 2004); and reproduces civilizational hierarchies that invalidate non-Western knowledge traditions, modes of social organization, and forms of subjectivity and relationality (Andreotti, 2011; Nandy, 2000; Santos, 2007).

When confronted with challenges to the benevolence or universality of liberal global ethics, its practitioners and proponents tend to have one of two responses: either dismissing the challenge outright or selectively incorporating elements of different ethical traditions in ways that nonetheless do not challenge the liberal grid of value and intelligibility. The latter response tends to result in familiar forms of liberal pluralism, which only allow for "difference that makes no difference" (Ahmed, 2016). If the presumed universality of liberalism's global imaginary is not punctured, then these responses to critique become circular, offering different ethical content within the same underlying frames. Therefore, we are not suggesting the need for a shift or a change within the dominant (liberal) imaginary, but argue instead for this imaginary to be considered alongside other possible imaginaries and subsequent approaches to global ethics. We argue for its repositioning and de-universalization rather than the reform of its content. In this, we emphasize the need to challenge its hegemony so as to open up other possibilities for (co)existence, in particular those that are unimaginable within liberalism's cognitive, imaginative and discursive frameworks. However, this does not mean that the liberal global imaginary offers no gifts, nor that we merely seek to replace it with a different hegemonic imaginary. It simply means that there are many other possibilities and discussions that cannot be held-or are not considered possible, legible or legitimate-if liberalism's demands for universal solutions and consensus continue to set the agenda and terms of conversations (see Santos, 2007). Below we review critical approaches that question the universality of liberalism's global imaginary. 


\section{Critical Approaches to Global Ethics}

Critical approaches to global ethics vary in their exact emphasis, but invariably identify an enduring set of power relations on an international scale-(geo)political, economic, epistemological, ecological-and problematize how these relations shape dominant conversations about ethics. In particular, attention is paid to how ethical responses articulated within a liberal global imaginary tend to present ethical dilemmas in dehistoricized and depoliticized ways that reproduce unequal power relationships, support simplistic analyses of and responses to structural violence, and naturalize ethnocentric imaginaries of responsibility and change. For instance, Stone-Mediatore (2011) finds that scholarship and pedagogy in the field of global ethics emphasizes "almost exclusively" white authors in the tradition of Western philosophy. She notes that although "Eurocentrism in academia is nothing new...in a field such as global ethics that aims to treat moral problems in their cultural and geographic breath, the exclusion of viewpoints from the majority of the world's cultures and countries is particularly troubling" (p. 45).

In response to the identified shortcomings of liberal global ethics, a critical approach to global ethics recognizes the need to redistribute resources, democratize governance, and pluralize knowledge traditions within mainstream institutions. The idea is that if we achieve a more diverse representation of perspectives and distribution of power and resources in the political, economic, and epistemological dimensions of global society, then we will achieve a more equitable set of global relations. However, it is challenging for even critical people who are socialized into the presumption of liberal universality to access other ethical traditions without selectively extracting and consuming difference and inserting it back into existing, dominant frames and horizons of hope. In addition, it is difficult to envision a radically different future from where we currently stand, because the liberal global imaginary is so effective at foreclosing alternatives. A critical ethical approach is therefore articulated from the edge of liberal frames of global ethics, but it does not necessarily go beyond them, often closing off viable possibilities that are not yet imaginable from within those frames. A decolonial approach to global ethics seeks to address the ambivalences, complexities, circularities, and complicities that are often involved in trying to imagine ethics "otherwise."

\section{Decolonial Approaches to Global Ethics}

A decolonial approach to ethics emphasizes and denaturalizes the enduring coloniality of the liberal global imaginary and the institutions and social relations that it engenders, and which in turn uphold it. Coloniality refers to "long-standing patterns of power that emerged as a result of colonialism, but that define culture, labor, intersubjective relations, and knowledge production well beyond the strict limits of colonial administrations" (Maldonado-Torres, 2007, p. 243). These patterns have instituted a racialized regime of differential value that serves to rationalize and even naturalize the processes that produce economic and political inequality, and to enact genocidal and ecocidal practices of exploitation, extraction, and expropriation for the ends of capital accumulation. Notably, colonial social relations and representations do not simply negatively affect racialized populations, they also serve as the conditions of possibility for the liberal imaginary and institutions by shaping the ecological, affective, cognitive, relational, and economic dimensions of our collective existence. From a decolonial perspective, this does not mean 
that Western traditions have nothing to offer, but rather that their purported universalization has been subsidized by racial and ecological violence; thus, they need to be interrupted and decentred so that suppressed ethical frameworks can be regenerated and new possibilities for (co)existence can emerge.

A decolonial approach to ethics therefore recognizes the gifts as well as the colonizing tendencies of both Western liberal and critical ethical traditions, and seeks to engage with existing and emergent alternative ethical possibilities. As part of this, a decolonial approach also recognizes the immense power of the liberal global imaginary, and the difficulties of imagining and enacting ethics otherwise. This also points to the ambivalence of the term "decolonial" itself, and our own ambivalence around its use here. As a "decolonial turn" has emerged in the context of educational scholarship, the meaning of the term "decolonial" has become contested. At times, it is used in metaphorical ways that betray the material dimensions of decolonization related to the restoration of stolen lands and resources (Patel, 2014; Tuck \& Yang, 2012). At other times, it is used in prescriptive ways that fail to attend to the many complex means through which contemporary existence is produced by colonialism (in its ecological, cognitive, affective, relational, and economic dimensions), and as such, cannot be transcended simply through stating that we intend to do so (Andreotti, 2016). Recognizing this complexity and difficulty, we cautiously describe the decolonial perspective as an ethical orientation that looks toward a horizon "beyond" colonialism without prescribing or demanding a guaranteed path to a fully decolonized future, and engages non-Western ethical frameworks without claiming to "master" them. It is a gesture or a glimpse toward enacting and embodying not only alternative ways of thinking (epistemologies) but also other ways of being (ontologies).

A decolonial approach to ethics is therefore articulated and practiced from the edge of dominant liberal ethical frames, looking outward toward other possibilities, but committed to learning from the mistakes of the liberal frames and cautious of the many difficulties that arise in trying to engage beyond them. This approach dwells in the messy spaces between what is imaginable in liberal ethics, critiques of those ethics, and alternative ethical frameworks that are unintelligible or illegitimate for those who remain invested in liberal frames. This approach recognizes the need for an ethical plurality that holds and learns from apparent paradoxes and incommensurabilities, as in the Zapatistas' decolonizing vision of "a world in which other worlds fit" (as cited in Grosfoguel, 2012, p. 99). But it also suggests that to create such a world would require first denaturalizing the global imaginary that has been naturalized by liberalism's institutions and subjectivities, as well as the material infrastructures that support their reproduction; otherwise, the result would be a return to the limited formations of liberal pluralism.

Thus, a decolonial approach to ethics also identifies a need for transitional practices, pedagogies, and engagements through which those who were socialized within a liberal global imaginary can work through not only the cognitive and material but also the affective and relational challenges of change. These challenges include unlearning ongoing investments in epistemic universality; processing affective resistances that arise when one is expected to "give up" perceived entitlements to economic advantage, political authority, and moral superiority; engaging responsibly and humbly with different ethical frames; and learning to relate to one another and the world in ways that are not oriented by rational, utility-maximizing choices to engage in collaboration or competition, but 
rather by humility, compassion, generosity, and affirmation of collective responsibilities (before will) as part of a wider social and ecological metabolism.

Finally, we note that engaging a decolonial approach to ethics in the Canadian context does not simply involve international relationships, but also the country's settler-colonial foundations. Indeed, a decolonial approach requires examining how coloniality operates in both local and global dimensions, and considering how different colonial regimes and relationships intersect in complex ways (Beck, 2012; Thobani, 2007).

\section{Ethical Approaches to Practices of Internationalization}

In the following section, we explore the possibilities and limitations of each of the three reviewed approaches to global ethics (liberal, critical, and decolonial) by asking how each would respond to practices of higher education internationalization as they relate to international students, study and service abroad, and internationalizing the curriculum. Our intention in offering these illustrative questions is not to suggest that we simply need to ask them, identify the "answers," and then we will know how to enact and embody a particular set of ethics so as to resolve ethical dilemmas. Rather, we offer the questions as a means to invite ongoing, self-reflexive conversations-among both international higher education scholars and educational practitioners-that might enable a deeper and more complex understanding of both the ethical challenges that are posed by internationalization and of different ways of responding to them, each of which enables certain possibilities and forecloses others.

\section{International Students}

In 2017, the United States and United Kingdom received the first and second highest number of international students, respectively, while Canada was the fourth most popular destination (OECD, 2017). As in many other Western anglophone nations, after the Second World War, international students studying in Canada were understood to play a central role in the development of their home countries, serving as transmitters of knowledge as well as vectors of international goodwill and trade (McCartney, 2016; Stein \& Andreotti, 2016; Trilokekar, 2010). Shifts in international student recruitment rationales, from development-based to income-generation-based, began to occur even before the end of the Cold War (Cudmore, 2005; McCartney, 2016), although in both the post-war and contemporary era, there has been a strong emphasis on benefits for international trade.

Today, international student tuition and fees are unregulated in Canada, as they are in many countries of the Global North (Bolsmann \& Miller, 2008; Ziguras, 2016). These fees are often many times higher than domestic students' tuition and fees at public institutions, as international students are understood to be an appealing source of revenue for many institutions (Anderson, 2015; Lee, Maldonado-Maldonado, \& Rhoades, 2006). Many host countries also emphasize the importance of recruiting international students, given that they bring non-tuition spending, tax revenues, and job creation (Altbach, 2004; Marginson, 2006; Owens, Srivastava, \& Feerasta, 2011). For instance, Canada's federal international education strategy emphasizes that "international students in Canada provide immediate and significant economic benefits to Canadians in every region of the country" (Department of Foreign Affairs, Trade and Development, 2014, p. 7), and also emphasizes billions of dollars in student spending, hundreds of millions of dollars in tax revenue, and job creation. 
In addition to the direct income they bring, international students are understood to be "ideal" future immigrants to Canada (Scott, Safdar, Trilokekar, \& El Masri, 2015). This is particularly relevant for policy makers who believe we are operating within a global "knowledge economy," in which countries compete to either retain or attract highly skilled persons in what Gibb and Walker (2011) describe as a "global war for talent" (p. 389). In the context of a highly uneven geopolitical landscape, Global North countries like Canada are the primary beneficiaries of this "war" (Altbach \& Knight, 2007; Johnstone \& Lee, 2014). A growing body of work also addresses the racism and xenophobia experienced by international students in Canadian higher education institutions (Coloma, 2013; Guo \& Guo, 2017; Stein \& Andreotti, 2016).

The liberal global ethics approach presumes that Western higher education represents the height of human knowledge and development. However, there is concern that current trends in international student mobility rob human capital from sending countries through the process of "brain drain," the one-way migration of highly educated students from their home countries in the Global South to the Global North (Adnett, 2010; Rizvi \& Lingard, 2010). Indeed, Canada in particular has been criticized for contributing to brain drain in the health professions (Crush, 2002, as cited in Neiterman, Atanackovic, Covell, \& Bourgeault, 2018). A liberal ethics approach might emphasize that a preferred option is "brain circulation," in which exceptional students from the Global South are educated in the Global North and bring their acquired skills back home with them to contribute to national development (Marginson, 2006). This is a return to the Cold War approach to international student mobility as development aid (O'Mara, 2012). Domestic and international student engagements are also understood to as a means for both groups to develop "intercultural competence," although it is generally emphasized that "international students are valuable contributors of diverse cultural perspectives and experiences" (Leask, 2009, p. 206) in ways not assumed of their domestic peers.

A critical approach to the ethics of international student mobility problematizes liberal ethics for not interrupting the transnational economic elitism of the existing admissions system, which creates significant material and other barriers to access. Viggiano, López Dámian, Morales Vázquez, and Levin (2017) found that the presumption of international student affluence can lead to a situation where access is not extended to students from low-income backgrounds and/or from low-income countries. In response, some scholars advocate for extending national equity commitments to international students (Tannock, 2013), or suggest that international students should pay the same fees as domestic students (Enslin \& Hedge, 2008). Notwithstanding their critical orientation, these approaches do not necessarily question the presumption that Western higher education is superior. Instead, their primary ethical concerns centre on how to best ensure more expansive and equitable access to Western higher education, and to ensure better institutional treatment for those who do enrol. In Canada in particular, scholars have documented that some universities make promises to international students about the academic support that will be offered and available post-graduation immigration opportunities, which often fail to match up with reality (Guo \& Guo, 2017; Brunner, 2017; Neiterman et al., 2018). Finally, a critical ethical approach emphasizes that racism against international students needs to be addressed at a systemic, institutional level, rather than merely as a product of individual bias (Lee \& Rice, 2007; Rhee \& Sagaria, 2004). 
Rather than proposing particular interventions to increase access, a decolonial approach to ethics emphasizes the material and epistemic frames that naturalize both liberal and critical desires for Western higher education. It traces the colonial histories of uneven geopolitical economic relations that produced the presumption and promise of Western education as the path to individual and national development. In this way, it understands both the Western university's desire to recruit international students and the international students' desire to attend the Western university within a shared global imaginary (Kim, 2011; Nandy, 2000; Stein \& Andreotti, 2016; Wyly \& Dhillon, 2018). Further, a decolonial approach suggests that inclusion is generally offered to international students on the condition that they participate in, or at least do not challenge, the national exceptionalist ethos of a place like Canada, which is itself premised on local and global colonial continuities and complicities (Stein, 2018; Thobani, 2007). This approach to ethics does not dismiss concerns about extractive tuition fees or minimize the need to address both interpersonal and institutional racism directed at international students. Instead, it suggests that high fees and racist practices are embedded within the same root colonial schema of differential value that asserts Western benevolence, supremacy, and universalism. Thus, for a decolonial approach, addressing individual and institutional barriers and biases is important but also insufficient for dismantling the epistemological, economic, and geopolitical hegemonies that characterize the global higher education landscape (Stein \& Andreotti, 2016; Wyly \& Dhillon, 2018).

Table 1 illustrates the kinds of questions that each ethical approach prioritizes in relation to policies and practices in the context of student mobility in higher education.

\section{Study and Service Abroad}

Considerable internationalization efforts go into enhancing credit-bearing study abroad offerings and increasing and diversifying domestic students' participation in these programs (Salisbury, Paulsen, \& Pascarella, 2011). These programs may take the form of short- or long-term experiences. International service learning (ISL) is another increasingly popular form of experiential learning and international educational engagement in which university students (generally from wealthier parts of the world) travel abroad to engage in a community-based service activity (generally in poorer parts of the world) (Crabtree, 2008). These programs vary in terms of the formality of academic instruction, trip length, and other variables. Similar programs have been described as "voluntourism," which Khoo (2011) characterizes as a blend of "travel, volunteering and fundraising to cover the cost of development projects and travel costs" (p. 346), but compared to ISL, voluntourism may lack a structured learning component. In her study of a celebrated research and learning partnership between a Canadian university and a Tanzanian community, Larsen (2015) found that while there were some benefits for the various participants there was nonetheless an underlying "assumption that Canadian universities can solve African problems" (p. 118), which reproduced colonial relations and deficit orientations. The different ethical approaches presented in this paper have different perspectives on the intended and actual effects and outcomes of international study and service abroad programs, and each might frame the transformative potential of these programs in somewhat different ways. 


\section{Table 1. Ethical questions about international student mobility from each approach}

\begin{tabular}{ll}
\hline Liberal & How can we ensure that international students, their host countries, and their \\
& home countries all benefit from their educational experience abroad? How can \\
we prepare international students to become effective leaders in their home \\
countries? How can we foster positive engagements between international and \\
domestic students? How can we prepare domestic staff and students to be more \\
culturally sensitive toward international students? \\
Critical \\
How can we democratize international access to our universities and recruit a \\
more diverse and globally representative student body? What promises do Cana- \\
dian/Western universities offer to potential international students, and how do \\
these compare with benefits actually received? How can we address racism in all \\
areas of the institution, including admissions, curriculum design, and evaluation, \\
as well as interpersonal engagements? \\
What economic and geopolitical histories and relations have made the West a \\
desired location for international study? What different motivations drive inter- \\
national students to study abroad? How can we understand international students \\
as neither victims or villains, but rather as complex subjects with conflicting de- \\
sires who might be both subject to and complicit in others' marginalization? Does \\
expanding access to Canadian/Western universities for a subset of students alter \\
or reproduce the uneven global higher education landscape? How might we de- \\
naturalize assumptions about the superiority of Western(ized) higher education?
\end{tabular}

Liberal ethical approaches to study and service abroad presume that students who participate in these programs will develop important intercultural skills and global awareness. While some emphasize that these will make students better prepared to compete in a global job market and collaborate in diverse workplaces (Baillie Smith \& Laurie, 2011), others emphasize how participation in these international programs contributes to the development of participating students' moral and civic leadership capacities (Bringle, 2011), global citizenship competencies (Dolby, 2004; Longo \& Saltmarsh, 2011), and deepened appreciation of human diversity (Nussbaum, 2002). This approach also has a humanitarian dimension, organized around the presumption of participating students' "sense of duty and fairness in the world: those who can supporting those who cannot, giving opportunities to those left behind" (Butin, as cited in Sin, 2009, p. 482). Transformation within a liberal ethical approach emphasizes the enhancement of individuals' self-knowing and the expansion of possibilities for cross-cultural collaborations, which are nonetheless led by liberal subjects who are presumed to have reached the highest level of human progress and development (Silva, 2007; Smith, 2012).

Critical ethical approaches to study and service abroad emphasize the risk of reifying racial stereotypes and reproducing harm in the host community if there is inadequate practical and pedagogical preparation for the experience (Grusky, 2000). Beyond direct harm, there is concern that these experiences can also reproduce students' presumed entitlements and supremacies. According to Zemach-Bersin (2007), in most framings of study abroad, "the 'globe' is something to be consumed, a commodity that the privileged... student has the unchallenged and unquestioned right to obtain as an entitled citizen of the world" (p. 26). Meanwhile, Bryan (2012) argues that ISL programs "present citizens 
of the global South as objects of pity and benevolence, serve to obscure global power relations and prevent individuals from seeing how they themselves are implicated in sustaining such relations by participating in, and deriving benefits from, harmful global economic institutions and practices" (p. 21). In turn, the service experience enhances the cultural capital and resume of the student volunteer, and reaffirms their presumed benevolence and innocence (Angod, 2015; Baillie Smith \& Laurie, 2011). Some responses from a critical ethical approach therefore advocate for abolishing these programs altogether, while others emphasize the need to centre social justice and transformative social change (Butin, 2007; Tiessen \& Huish, 2014). For instance, in his analysis of Canadian educational programming on global citizenship, Jefferess (2008) argues for the need to frame relationships and responsibilities in consideration of "the history of imperial politics that has shaped the current world system" (p. 31).

A decolonial approach to ethics shares many of the critiques of study abroad and service-learning offered by the critical approach, as well as its ambivalence about the possibilities for fostering reciprocity or solidarity. But while a decolonial approach emphasizes the importance of justice-oriented frameworks for service and study abroad, it is be wary of imposing or importing Western-derived notions of justice into the intercultural context (Moallem, 2006). That is, there is wariness about the naturalization of a universal ethical system in which the critical Western student or scholar imposes their vision or theory of social transformation onto the host country or community (Gaztambide-Fernández, 2012). To do so would risk reproducing old colonial relations, only this time in the name of liberation (Spivak, 1988). Instead, the decolonial approach would stress the imperative to unlearn systems of domination and learn to listen to and serve host communities (rather than assuming that visiting students already know how to do so, or know what people in these communities want), while also remaining sceptical about our own motivations, our ability to "hear" what is being said, and our own transparency to ourselves. This also means attending to the ways that even visiting students who seek to "do the right thing" often remain at least partially invested in affirming their own benevolence, arbitrating justice, and determining the nature of their relationships with communities, out of a desire for and perceived entitlement to certainty, moral redemption, and control (see also Sutherland, 2018). It is precisely because these kinds of desires and perceived entitlements are not easily identified, let alone unlearned or unravelled, that we describe the decolonial ethical approach as an orientation that gestures toward a horizon, and an ongoing process that will entail mistakes and missteps, rather than as a prescriptive approach for how to "do" decolonization the "right" way.

Table 2 illustrates the kinds of ethical questions that each approach would prioritize in relation to study and service abroad.

\section{Internationalizing the Curriculum}

As universities increasingly recruit international students and send more domestic students to study and volunteer abroad, many have emphasized the need to also "internationalize the campus," sometimes also called "internationalization at home." For Wächter (2003), internationalization at home is premised on "an understanding of internationalisation that [goes] beyond mobility and a strong emphasis on the teaching and learning in a culturally diverse setting" (p. 6). Harrison (2015) suggests that it "offer[s] a democratisation of the benefits of internationalisation to a much wider segment of society than that 
which could be, or wanted to be, geographically mobile" (p. 414). A primary emphasis of these more local internationalization efforts has been on transforming curricula (Clifford \& Montgomery, 2015).

Table 2. Ethical questions about study and service abroad from each approach
Liberal
How can study/service abroad inspire students to become engaged global citi- zens and leaders with a sense of responsibility that goes beyond themselves and their nation? How can a more diverse set of students gain access to these pro- grams? How can international service trips prompt students to recognize their relative advantage and give back to the host community?
Critical What systems and policies reproduce the uneven distribution of wealth that gives (certain) students the opportunity to travel from Canada or elsewhere in the Global North to the Global South? How does the structure of the service relation risk reproducing "white saviourism" and naturalizing inequality? What pedagogi- cal scaffolding do students need before, during, and after these trips in order to denaturalize their presumed supremacies? What kinds of frameworks do stu- dents need in order to be able to reflexively attend to their own responses to their experiences abroad, so that they can learn from these responses and minimize harm to others?

Decolonial How can visiting students learn to listen to the needs, desires, and dreams of host communities? How should it be handled when the ethical frameworks of visiting students conflict with those of the host community? How do we prepare students to deal with the heterogeneity and internal contradictions of the host community, and to respect and revere their gifts without romanticizing or idealizing them? How can students begin to understand that in order to truly remake relationships between communities they will need to disinvest from their presumed entitlements and desires for affirmation, certainty, universality, choice, and control, and develop a sense of responsibility to (rather than for) all living beings?

Leask (2015) defines curriculum internationalization as "the incorporation of international, intercultural, and/or global dimensions into the content of the curriculum as well as the learning outcomes, assessment tasks, teaching methods, and support services of a program of study" (p. 9). According to the Association of Universities and Colleges in Canada (now Universities Canada), the purpose of internationalizing Canadian university curricula is to "to prepare graduates who are internationally knowledgeable and interculturally competent" (as cited in Fuller \& Liu, November 2009, p. 1). Internationalization of the curriculum has also been framed as a way to be more responsive to the epistemological perspectives of international students (Harrison, 2015). However, in their research at a Canadian university with strong stated commitments to internationalize the curriculum, Guo and Guo (2017) found that some international students "reported that they felt there were few teaching and learning resources that were related to their experiences" (p. 859) and that they were confronted with racism and stereotypical representations of their home countries. Foster and Anderson (2015) suggest, "We are on the journey of our understanding of internationalized curriculum where the complex nature of [internationalizing the curriculum] is only just beginning to be grasped by theorists and practitioners" 
(para. 1); yet even in these initial stages, there are many ethical questions involved, and divergent possible ways of framing and addressing them.

Harrison's (2015) framing of curriculum internationalization exemplifies a liberal ethical approach, incorporating international content, international perspectives, and an emphasis on intercultural engagements. This approach focuses on the learner's selfactualization and follows the notion that knowledge about cultural difference will prepare individuals to engage more fruitfully in interpersonal relationships, better compete within a global labour market, and foster smoother relations between different countries and peoples. From this perspective, internationalization of the curriculum is framed as a means to prepare "students to be global citizens who can operate in a globalized world" (Sawir, 2013, p. 361). However, formal respect for difference does not necessarily entail interrogation or interruption of the power relations that shape cross-cultural learning, nor challenge the universal claims that characterize Western knowledge production. For instance, Hail (2015) suggests that "if Western educators want to encourage Chinese students to appreciate pluralism and think about how democracy works, then showing students examples of the expression of civil rights in democratic countries may be more effective than directly criticizing China's human rights situation” (p. 11). In this example, there is a welcome emphasis on respectful engagements with difference, yet this approach is framed as a means to the end of demonstrating to Chinese international students the superiority of the Western liberal political system.

A critical approach to the ethics of curriculum internationalization emphasizes the insufficiency of efforts to include marginalized knowledges that do not also address the racialized and gendered political economy of knowledge production (Connell, 2007). This epistemic economy delegitimizes or devalues not only knowledges produced in other (nonWestern) countries, but also knowledge that is produced by non-white people within the West (Roshanravan, 2012). From this position, the ethical imperative is to denaturalize and decentre Western knowledges (Breit, Obijiofor, \& Fitzgerald, 2013), and to dedicate more material resources to the support of the production and instruction of marginalized knowledges, including through hiring faculty, revising existing awards and promotion procedures, expanding access through increased funding opportunities for students from historically marginalized populations, and reconsidering the Eurocentric perspectives that dominate curricula in nearly every academic department. In Canada, efforts to "internationalize" the curriculum may or may not be considered alongside recent commitments to "Indigenize" curriculum, but in both cases, the hope is that by institutionalizing support for marginalized knowledges and including more members of marginalized populations the institution itself will be transformed.

A decolonial approach to the ethics of curriculum internationalization also critiques the geo- and body-political economy of knowledge production, but emphasizes that the frames of Western knowledge are actively invested in the devaluation of non-Western ways of knowing in order to maintain the claim of Western universality and, thus, the foreclosure of anything that would challenge its epistemic, moral, and other forms of authority (Spivak, 1988, 1990; Maldonado-Torres, 2007; Santos, 2007). This approach thus emphasizes the contradictions, conflicts, and circularities that might arise when divergent knowledge systems meet. In particular, when different ways of knowing are instrumentalized by institutions and subject to selective/conditional inclusion (Ahmed, 2012; Mitchell, 2015; Nandy, 2000), this may result in non-Western ways of knowing being "grafted" 
onto Western ways of being, denying the powerful potential of these knowledges to open up truly different horizons of possibility (Ahenakew, 2016). Thus, for the decolonial approach, simply adding and supporting more diverse knowledges does not in itself necessarily pluralize possibilities for (co)existence. To do so would require not just incorporating alternative knowledges into existing institutions and decentring Western knowledge, but also reframing different knowledge systems as contextually relevant interventions into reality that both enable and foreclose different possibilities (Santos, 2007). Alongside epistemic reframing, there would also be a need for the "redistribution of material, social, political, cultural, and symbolic resources" that have historically been extracted and hoarded in ways that naturalize not only Western epistemic universality but also other forms of Western domination (Santos, 2007, p. 64). However, beyond redistributing these resources within existing material, social, political, cultural, and symbolic economies, the decolonial perspective has a commitment to ultimately rethink the orienting logics, ontological grammars, and infrastructures of those economies and consider other possibilities for (co)existence. This means considering not only different epistemologies, but different ontologies as well.

Table 3 illustrates the kinds of ethical questions that each approach would prioritize in relation to internationalizing curricula in higher education.

\section{Table 3. Ethical questions about curriculum internationalization from each approach}

\begin{tabular}{l}
\hline Liberal \\
can all disciplines, and in particular science, technology, engineering, and math \\
(STEM) fields, incorporate an international dimension to their programs? How \\
can we encourage international students to share their knowledge in the class- \\
room as a means of fostering epistemic pluralism and democratic deliberation? \\
What are the essential knowledge and skills needed to ensure that students \\
graduate with cultural competency?
\end{tabular}

Critical How can we ensure that diverse knowledges are not simply included in curriculum, but valued, supported, and rewarded? What is needed to build enduring institutional capacity for teaching and research outside of Western knowledge traditions? How can we ensure that all students gain an appreciation for the gifts of minoritized knowledges, and that marginalized students in particular have access to these knowledges?

Decolonial How can we shift dominant relationships to knowledge from the search for absolute truth to appreciation of contextual relevance? How can we prepare students to navigate complexity and uncertainty in a rapidly changing world with no clear epistemic authorities? How can students learn to distinguish between the known, the unknown, and the unknowable? How can we make institutions into spaces of true epistemic pluralism, given the tendency to suppress knowledge systems that challenge not only Western epistemic hegemony but also dominant modes of ecological, relational, and economic organization? How can we go beyond recognizing the effects of colonialism's epistemological dominance in order to recognize its ontological dominance as well? 


\section{Conclusion: Caveats and Further Steps}

In this paper, we have sought to contribute to the pluralization of possible responses to ethical dilemmas related to the multiple facets of internationalization in higher education, both in Canada and elsewhere. Through a (non-exhaustive) mapping of three possible approaches to global ethics (liberal, critical, and decolonial), we have considered how questions related to global ethics could be articulated differently when conceptualized through each of these approaches. While research on divergent articulations of global ethics in internationalization remains relatively scarce, recent studies suggest that internationalization practice and policy in Canadian higher education institutions remains predominantly framed by (neo)liberal discourse, along with several instances/examples of critical approaches, and with a near absence of what might be considered decolonial approaches (Pashby \& Andreotti, 2016; Suša, 2016; Stein, 2018). While this paper is an invitation to expand existing conversations about internationalization beyond mainstream liberal imaginaries of global ethics and towards more equivocal conversations that would also encompass critical and decolonial approaches, we recognize that this work must also attend to and account for the enduring uneven power relations and resources that affect what is possible in any given context.

We began this paper by outlining some of the tensions and conflicts of interest that surround and shape internationalization efforts, in particular the conflict between the economic imperative for universities to capitalize on the financial opportunities afforded by internationalization and the ethical imperative to consider their commitments to social accountability and service to the (global) public good. Given the fact that the economic imperative is tightly linked to securing institutional resources during a time of declining public funding, emphasizing the ethical imperative (particularly in ways that challenge mainstream ethics approaches) may be perceived as undermining universities' prestige, epistemic privilege, and ultimately their economic stability and viability. In this context, it becomes necessary to ask: Are different conversations even possible?

In response to this question, we recognize the risk that even our attempts to engage global ethics from a critical or decolonial approach might be circumscribed or instrumentalized by the hegemonic (neo)liberal imperatives of internationalization. Because of this, and because of our general intention not to simply replace one hegemony with a (potentially) better one, we do not advocate for a "critical" or "decolonial" turn in the theory and practice of global ethics. Our intention is much more modest: We seek to point to an absence of conversations that we have not yet had, and which might enable different possibilities. While it is highly unlikely that mainstream institutional internationalization practices and policies will change any time soon, the kind of questions that can be opened by imagining internationalization through different kinds of approaches can nonetheless play an important and generative role-both educationally and relationally. If we can challenge dominant assumptions about what is possible and consider that there are other

possibilities that are viable but lie beyond what is currently imaginable, then we can create the potential for something new and different to emerge.

\section{Note}

1. Practitioners include those working in colleges and universities as international student advisors, admissions officers, and recruiters; those organizing co- and extra-cur- 
ricular international engagements, including short- and long-term study or serviceabroad programs; and any other administrative or student services staff involved in creating and/or implementing internationally related policies and programs.

\section{References}

Adnett, N. (2010). The growth of international students and economic development: Friends or foes? Journal of Education Policy, 25(5), 625-637. https://doi. org/10.1080/02680931003782827

Ahenakew, C. (2016). Grafting Indigenous ways of knowing onto non-Indigenous ways of being. International Review of Qualitative Research. 9(3), 323-340. https:// doi.org/10.1525/irqr.2016.9.3.323

Ahmed, S. (2012). On being included: Racism and diversity in institutional life. Durham, NC: Duke University Press.

Ahmed, S. (2016). How not to do things with words. Wagadu: A Journal of Transnational Women's and Gender Studies, 16, 1-8.

Altbach, P. (2004). Globalisation and the university: Myths and realities in an unequal world. Tertiary Education and Management, 1O(1), 3-25. https://doi.org/10.1023/ B:TEAM.oooo012239.55136.4b

Altbach, P., \& Knight, J. (2007). The internationalization of higher education: Motivations and realities. Journal of Studies in International Education, 11(3-4), 290305. https://doi.org/10.1177\%2F1028315307303542

Anderson, T. (2015). Seeking internationalization: The state of Canadian higher education. Canadian Journal of Higher Education, 45(4), 166-187.

Andreotti, V. (2011). Actionable postcolonial theory in education. Dordrecht, The Netherlands: Springer.

Andreotti, V. (2016). Multi-layered selves: Colonialism, decolonization, and counter-intuitive learning. ArtsEverywhere. Retrieved from http://artseverywhere. ca/2016/10/12/multi-layered-selves/

Angod, L. (2015). Behind and beyond the ivy: How schools produce elites through the bodies of racial others (Doctoral dissertation). University of Toronto.

Baillie Smith, M., \& Laurie, N. (2011). International volunteering and development: Global citizenship and neoliberal professionalisation today. Transactions of the Institute of British Geographers, 36(4), 545-559. https://doi.org/10.1111/j.1475-5661.2011.00436.x

Battiste, M. (2013). Decolonizing education: Nourishing the learning spirit. Vancouver: University of British Columbia Press.

Beck,K.(2012).Globalization/s: Reproductionandresistanceintheinternationalization of higher education. Canadian Journal of Education, 35(3), 133-148. http://journals. sfu.ca/cje/index.php/cje-rce/article/view/1077

Bolsmann, C., \& Miller, H. (2008). International student recruitment to universities in England: Discourse, rationales and globalisation. Globalisation, Societies and Education, 6(1), 75-88. https://doi.org/10.1080/14767720701855634 
Brandenburg, U., \& de Wit, H. (2011). The end of internationalization. International Higher Education, 62(Winter), 15-17. https://doi.org/10.6017/ihe.2011.62.8533

Breit, R., Obijiofor, L., \& Fitzgerald, R. (2013).Internationalizationasde-Westernization of the curriculum: The case of journalism at an Australian University. Journal of Studies in International Education, 17(2), 119-135. https://doi.org/10.1177\%2F1028315312474897

Bringle, R. G. (2011). Preface. In Bringle, R. G., Hatcher, J. A., \& Jones, S. G. (Eds.), International service learning: Conceptual frameworks and research (pp. ix-xvi). Sterling, VA: Stylus

Brunner, L. R. (2017). Higher educational institutions as emerging immigrant selection actors: A history of British Columbia's retention of international graduates, 2001-2016. Policy Reviews in Higher Education, 1(1), 22-41. https://doi.org/10.1080/ 23322969.2016.1243016

Bryan, A. (2012). Band-aid pedagogy, celebrity humanitarianism, and cosmopolitan provincialism: A critical analysis of global citizenship education. In Wankel, C. (Ed.) Ethical models and applications of globalization: Cultural, socio-political and economic perspectives, (pp. 262-286). Hershey, PA: IGI Global.

Butin, D. W. (2007). Justice-learning: Service-learning as justice-oriented education. Equity \& Excellence in Education, 4O(2), 177-183. https://doi. org/10.1080/10665680701246492

Canadian Bureau for International Education (CBIE). 2015. Canada's performance in international education, 2014. Ottawa, ON: Author.

Clifford, V., \& Montgomery, C. (2015). Transformative learning through internationalization of the curriculum in higher education. Journal of Transformative Education, 13(1), 46-64. https://doi.org/10.1177\%2F1541344614560909

Coloma,R.S.(2013).“TooAsian?”Onracism,paradoxandethno-nationalism.Discourse: Studies in the Cultural Politics of Education, 34(4), 579-598. https://doi.org/10.1080/o 1596306.2013.822620

Connell, R. (2007). Southern theory: The global dynamics of knowledge in social science. Crow's Nest, Australia: Allen \& Unwin.

Crabtree, R. D. (2008). Theoretical foundations for international servicelearning. Michigan Journal of Community Service Learning, 15(1), 18-36. https://quod. lib.umich.edu $/ \mathrm{m} / \mathrm{mjcsl} / 3239521.0015 .102 / 1$

Cudmore, G. (2005). Globalization, internationalization, and the recruitment of international students in higher education, and in the Ontario Colleges of Applied Arts and Technology. Canadian Journal of Higher Education, 35(1), 37-60. http://journals. sfu.ca/cjhe/index.php/cjhe/article/view/183491

Department of Foreign Affairs, Trade and Development. (2014). Canada's international education strategy: Harnessing our knowledge advantage to drive innovation and prosperity. Retrieved from http://international.gc.ca/global-marketsmarches-mondiaux/assets/pdfs/overview-apercu-eng.pdf 
Dolby, N. (2004). Encountering an American self: Study abroad and national identity. Comparative Education Review, 48(2), 150-173. https://doi. org/10.1086/382620

Donald, D. (2012). Forts, colonial frontier logics, and Aboriginal-Canadian relations. In A. A. Abdi (Ed.), Decolonizing philosophies of education (pp. 91-111). Rotterdam, The Netherlands: SensePublishers.

Dower, N. (2014). Global ethics: Dimensions and prospects. Journal of Global Ethics, 1O(1), 8-15. https://doi.org/10.1080/17449626.2014.896575

Drydyk, J. (2014). Foundational issues: How must global ethics be global? Journal of Global Ethics, 1O(1), 16-25. https://doi.org/10.1080/17449626.2014.896576

Enslin, P., \& Hedge, N. (2008). International students, export earnings and the demands of global justice. Ethics and Education, 3(2), 107-119. https://doi. org/10.1080/17449640802395984

Fisher, D., Rubenson, K., Shanahan, T., \& Trottier, C. (Eds.). (2014). The development of postsecondary education systems in Canada: A comparison between British Columbia, Ontario, and Quebec, 1980-2010. Montreal, QC: McGill-Queen's University Press.

Foster, M., \& Anderson, L. (2015). Editorial: Exploring internationalisation of the curriculum to enhance the student experience. Journal of Perspectives in Applied Academic Practice, 3(3), 1-2, https://doi.org/10.14297/jpaap.v3i3.206

Fuller, T., \& Liu, Q. (2009, November). The reality of internationalizing the curriculum at a Canadian polytechnic institution. Paper Presented at the Association for the Study of Higher Education Annual Meeting, Vancouver, BC.

Gandhi, L. (2011). The pauper's gift: Postcolonial theory and the new democratic dispensation. Public Culture, 23(1), 27-38. https://doi.org/10.1215/08992363-2010-013

Garson, K. (2016). Reframing internationalization. The Canadian Journal of Higher Education, 46(2), 19-39. http://journals.sfu.ca/cjhe/index.php/cjhe/article/ view/185272

Gaztambide-Fernández, R. A. (2012). Decolonization and the pedagogy of solidarity. Decolonization: Indigeneity, Education \& Society, 1(1), 41-67. https://jps.library. utoronto.ca/index.php/des/article/view/18633

Gibb, T., \& Walker, J. (2011). Educating for a high skills society? The landscape of federal employment, training and lifelong learning policy in Canada. Journal of Education Policy, 26(3), 381-398. https://doi.org/10.1080/02680939.2010.520744

Grosfoguel, R. (2012). Decolonizing Western uni-versalisms: Decolonial pluriversalism from Aimé Césaire to the Zapatistas. Issue: Transmodernity: Journal of Peripheral Cultural Production of the Luso-Hispanic World, 1(3). https://escholarship. org/uc/item/o1w7163v

Grusky, S. (2000). International service-learning: A critical guide from an impassioned advocate. American Behavioural Scientist, 43(5), 858-867. https://doi. org/10.1177\%2FooO27640021955513 
Guo, Y., \& Guo, S. (2017). Internationalization of Canadian higher education: Discrepancies between policies and international student experiences. Studies in Higher Education, 42(5), 851-868. https://doi.org/10.1080/03075079.2017.1293874

Hail, H. C. (2015). Patriotism abroad: Overseas Chinese students' encounters with criticisms of China. Journal of Studies in International Education, 19(4), 311-326. https://doi.org/10.1177\%2F1028315314567175

Harrison, N. (2015). Practice, problems and power in "internationalisation at home": Critical reflections on recent research evidence. Teaching in Higher Education, 2O(4), 412-430. https://doi.org/10.1080/13562517.2015.1022147

Hutchings, K. (2010). Global ethics: An introduction. Cambridge, England: Polity.

ICEF (2017, November). Canada's international student enrollment surged in 2016. ICEF Monitor. Retrieved from http://monitor.icef.com/2017/11/canadas-internationalstudent-enrolment-surged-2016/

Jefferess, D. (2008). Global citizenship and the cultural politics of benevolence. Critical Literacy: Theories and Practices, 2(1), 27-36. http://criticalliteracy.freehostia. com/index.php?journal $=$ criticalliteracy\&page $=$ article\&op $=$ viewArticle\&path\%5B $\% 5 \mathrm{D}=5$

Johnstone, M., \& Lee, E. (2014). Branded: International education and 21st-century Canadian immigration, education policy, and the welfare state. International Social Work, 57(3), 209-221. https://doi.org/10.1177\%2Fo020872813508572

Kapoor, I. (2014). Psychoanalysis and development: Contributions, examples, limits. Third World Quarterly, 35(7), 1120-1143. https://doi.org/10.1080/01436597.2014.926 101

Khoo, S. (2011). Ethical globalisation or privileged internationalisation? Exploring global citizenship and internationalisation in Irish and Canadian universities. Globalisation, Societies and Education, 9(3-4), 337-353. https://doi.org/10.1080/1476 7724.2011.605320

Kim, J. (2011). Aspiration for global cultural capital in the stratified realm of global higher education: Why do Korean students go to US graduate schools? British Journal of Sociology of Education, 32(1), 109-126. https://doi.org/10.1080/01425692.2011.527725

Kuokkanen, R. (2008). What is hospitality in the academy? Epistemic ignorance and the (im)possible gift. The Review of Education, Pedagogy, and Cultural Studies, 30(1), 60-82. https://doi.org/10.1080/10714410701821297

Larkin, A. (2015). North-South partnerships in Canadian higher education. In A. A. Abdi (Ed.), Decolonizing global citizenship education (pp. 141-155). Rotterdam, The Netherlands: SensePublishers.

Larsen, M. A. (2015). Internationalization in Canadian higher education: A case study of the gap between official discourses and on-the-ground realities. The Canadian Journal of Higher Education, 45(4), 101-122. http://journals.sfu.ca/cjhe/index.php/cjhe/ article/view/184907

Leask, B. (2009). Using formal and informal curricula to improve interactions between home and international students. Journal of Studies in International Education, 13(2), 205-221. https://doi.org/10.1177\%2F1028315308329786 
Lee, J. J., Maldonado-Maldonado, A., \& Rhoades, G. (2006). The political economy of international student flows: Patterns, ideas, and propositions. In J. C. Smart (Ed.), Higher education: Handbook of theory and research (pp. 545-590). Dordrecht, The Netherlands: Springer.

Lee, J. J., \& Rice, C. (2007). Welcome to America? International student perceptions of discrimination. Higher Education, 53(3), 381-409. https://doi.org/10.1007/s10734005-4508-3

Longo, N. V., \& Saltmarsh, J. (2011). New lines of inquiry in reframing international service learning into global service learning. In R. G. Bringle, J. A. Hatcher, \& S. G. Jones (Eds.), International service learning: Conceptual frameworks and research, 1, (Vol. 1, pp. 69-85). Sterling, VA: Stylus.

Maldonado-Torres, N. (2007). On the coloniality of being: Contributions to the development of a concept. Cultural Studies, 21(2-3), 240-270. https://doi. org/10.1080/09502380601162548

Marginson, S. (2006). Dynamics of national and global competition in higher education. Higher Education, 52(1), 1-39. https://doi.org/10.1007/s10734-004-7649-x

Marginson, S., \& Sawir, E. (2005). Interrogating global flows in higher education. Globalisation, Societies and Education, 3(3), 281-309. https://doi. org/10.1080/14767720500166878

McCartney, D. M. (2016). Inventing international students: Exploring discourses in international student policy talk, 1945-75. Historical Studies in Education/Revue d'histoire de l'éducation, 28(2). https://historicalstudiesineducation.ca/index.php/edu hse-rhe/article/view/4457

McEwan, C. (2008). Postcolonialism and development. London, England: Routledge.

Mitchell, N. (2015). (Critical ethnic studies) intellectual. Critical Ethnic Studies,1(1), 86-94. https://doi.org/10.5749/jcritethnstud.1.1.0086

Moallem, M. (2006). Feminist scholarship and the internationalization of women's studies. Feminist Studies, 32(2), 332-351. https://doi.org/10.2307/20459089

Nandy, A. (2000). Recovery of indigenous knowledge and dissenting futures of the university. In S. Inayatullah and J. Gidley (Eds.) The university in transformation: Global perspectives on the futures of the university (pp. 115-123). Westport, CT: Bergin and Harvey.

Neiterman, E., Atanackovic, J., Covell, C., \& Bourgeault, I. L. (2018, February). "We want to be seen as partners, not vultures of the world": Perspectives of Canadian stakeholders on migration of international students studying in health professions in Canada. Globalisation, Societies and Education. Advance online publication. https://doi. org/10.1080/14767724.2018.1440350

Nussbaum,M.(2002).Education for citizenshipin an era of globalconnection. Studies in PhilosophyandEducation,21(4-5),289-303.https://doi.org/10.1023/A:1019837105053

O’Byrne, D. (2017). Global ethics and civil society. London, England: Routledge. 
O'Mara, M. (2012). The uses of the foreign student. Social Science History, 36(4), 583-615. https://doi.org/10.1017/So14555320001049X

OECD (2017). Education at a glance - 2017. Retrieved from https://www.oecdilibrary.org/education/education-at-a-glance-2017_eag-2017-en

Owens, D. L., Srivastava, P., \& Feerasta, A. (2011). Viewing international students as state stimulus potential: Current perceptions and future possibilities. Journal of Marketing for Higher Education, 21(2), 157-179. https://doi.org/10.1080/08841241.2 $\underline{011.623730}$

Pashby, K., \& Andreotti, V. D. O. (2016). Ethical internationalisation in higher education: Interfaces with international development and sustainability. Environmental Education Research, 22(6), 771-787.

Patel, L. (2014). Countering coloniality in educational research: From ownership to answerability. Educational Studies, 5O(4), 357-377. https://doi.org/10.1080/00131946 .2014 .924942

Rhee, J. E., \& Sagaria, M. A. D. (2004). International students: Constructions of imperialism in the Chronicle of Higher Education. The Review of Higher Education, 28(1), 77-96. https://doi.org/10.1353/rhe.2004.0031

Rizvi, F., \& Lingard, B. (2010). Globalizing education policy. London, England: Routledge.

Roshanravan, S. (2012). Staying home while studying abroad: Anti-imperial praxis for globalizing feminist visions. Journal of Feminist Scholarship, 2(2), 1-23.

Salisbury, M. H., Paulsen, M. B., \& Pascarella, E. T. (2011). Why do all the study abroad students look alike? Applying an integrated student choice model to explore differences in the factors that influence white and minority students' intent to study abroad. Research in Higher Education, 52(2), 123-150. https://doi.org/10.1007/s11162-010-9191-2

Santos, B. D. S. (2007). Beyond abyssal thinking: From global lines to ecologies of knowledges. Review (Fernand Braudel Center), 45-89.

Sawir, E. (2013). Internationalisation of higher education curriculum: The contribution of international students. Globalisation, Societies and Education, 11(3), 359-378. https:// doi.org/10.1080/14767724.2012.750477

Scott, C., Safdar, S., Trilokekar, R. D., \& El Masri, A. (2015). International students as "ideal immigrants" in Canada: A disconnect between policy makers' assumptions and the lived experiences of international students. Comparative and International Education/ Éducation Comparée et Internationale, 43(3), 5. https://ir.lib.uwo.ca/cie-eci/vol43/ iss $3 / 5 /$

Silva, D. F. D. (2007). Toward a global idea of race. Minneapolis: University of Minnesota Press.

Sin, H. L. (2009). Volunteer tourism - "involve me and I will learn"? Annals of Tourism Research, 36(3), 480-501. https://doi.org/10.1016/j.annals.2009.03.001

Smith, L.T. (2012). Decolonizing methodologies: Research and Indigenous peoples. Zed Books Ltd. 
Spivak, G.C. (1988). Can the subaltern speak? In C. Nelson \& L. Grossberg (Eds.), Marxism and the interpretation of culture (pp. 24-28). Champaign: University of Illinois Press.

Spivak, G. C. (1990). The post-colonial critic: Interviews, strategies, dialogues. New York, NY: Routledge.

Spivak, G. C. (2004). Righting wrongs. The South Atlantic Quarterly, 103(2/3), 523581. https://doi.org/10.1215/00382876-103-2-3-523

Stein, S. (2018). National exceptionalism in the "EduCanada" brand: Unpacking the ethics of internationalization marketing in Canada. Discourse: Studies in the Cultural Politics of Education, 39(3), 461-477. https://doi.org/10.1080/01596306.2016.1276884

Stein, S., \& Andreotti, V. D. O. (2016). Cash, competition, or charity: International students and the global imaginary. Higher Education, 72(2), 225-239. https://doi. org/10.1007/s10734-015-9949-8

Stein, S., Andreotti, V. D. O., \& Suša, R. (2016). “Beyond 2015”: Within the modern/ colonial global imaginary? Global development and higher education. Critical Studies in Education. Advanced online publication. https://doi.org/10.1080/17508487.2016.12477 37

Stein, S., Hunt, D., Suša, R., \& Andreotti, V. D. O. (2017). The educational challenge of unraveling the fantasies of ontological security. Diaspora, Indigenous, and Minority Education, 11(2), 6979. https://doi.org/10.1080/15595692.2017.1291501

Stone-Mediatore, S. (2011). A not-so-global ethics: Contradictions in U.S. global ethics education. Philosophy in the Contemporary World, 18(1), 43-57.

Suša, R. (2016). Modern global imaginaries, modern subjects, enduring hierarchical relations and other possibilities. Postcolonial Directions in Education, 5(2), 193-216. Retrieved from https://www.um.edu.mt/library/oar//handle/123456789/20126

Sutherland, A. (2018). Exploring the possibilities of a post-critical approach to student north-south mobility experiences: A case study of a social innovation and community development program in Fortaleza, Brazil. (Unpublished master's thesis). University of British Columbia, Vancouver. Retrieved from https://open.library.ubc.ca/ cIRcle/collections/24/items/1.0363916

Tannock, S. (2013). When the demand for educational equality stops at the border: Wealthy students, international students and the restructuring of higher education in the UK. Journal of Education Policy, 28(4), 449-464. https://doi.org/10.1080/02680939. 2013.764577

Thobani, S. (2007). Exalted subjects: Studies in the making of race and nation in Canada. Toronto, ON: University of Toronto Press.

Tiessen, R., \& Huish, R. (Eds.). (2014). Globetrotting or global citizenship?: Perils and potential of international experiential learning. Toronto, $\mathrm{ON}$ : University of Toronto Press. 
Trilokekar, R. D. (2010). International education as soft power? The contributions and challenges of Canadian foreign policy to the internationalization of higher education. Higher Education, 59(2), 131-147. https://doi.org/10.1007/s10734-0099240-y

Tuck, E., \& Yang, K. W. (2012). Decolonization is not a metaphor. Decolonization: Indigeneity, Education \& Society, 1(1), 1-40. https://jps.library.utoronto.ca/index.php/ des/article/view/18630

Universities Canada. (2014). Canada's universities in the world: AUCC internationalisation survey. Ottawa: Author.

Usher, A., (2018). The state of post-secondary education in Canada, 2018. Toronto, ON: Higher Education Strategy Associates.

Viggiano, T., López Damián, A. I., Morales Vázquez, E., \& Levin, J. S. (2017). The others: Equitable access, international students, and the community college. Journal of Studies in International Education, 22(1), 71-85. https://doi.org/10.1177\%2F1028315317725883

Wächter, B. (2003). An introduction: Internationalisation at home in context. Journal of Studies in International Education, 7(1), 5-11. https://doi.org/10.1177\%2F102831 5302250176

Widdows, H. (2011). Global ethics: An introduction. New York, NY: Routledge.

Wyly, E. K., \& Dhillon, J. K. (2018). Planetary Kantsaywhere: Cognitive capitalist universities and accumulation by cognitive dispossession. City, 22(1), 130-151. https:// doi.org/10.1080/13604813.2018.1434307

Zemach-Bersin, T. (2007). Global Citizenship and study abroad: It's all about US. Critical Literacy: Theories and Practices, 1(2), 16-28. http://www.criticalliteracyjournal. org/cljournalissue2volume1.pdf

Ziguras, C. (2016). And fairness for all? Equity and the international student cohort. In Student Equity in Australian Higher Education (pp. 207-220). Singapore: Springer Singapore.

\section{Contact Information}

Sharon Stein

Department of Educational Studies

University of British Columbia

sharon.stein@ubc.ca

Sharon Stein is an Assistant Professor in the Department of Educational Studies at the University of British Columbia. Her work emphasizes the social foundations and political economy of higher education, and how these relate to the contemporary decolonization, internationalization, and privatization of universities. By identifying the limits and harms of existing horizons of justice, responsibility, and change, she seeks to both gesture toward different possible futures and engage with the educational challenges of transformation. She is the convener of the Critical Internationalization Studies Network. 
Vanessa Andreotti is a Professor in the Department of Educational Studies at the University of British Columbia, and holds a Canada Research Chair in Race, Inequalities and Global Change. Her research focuses on analyses of historical and systemic patterns of reproduction of knowledge and inequalities and how these mobilize global imaginaries that limit or enable different possibilities for (co)existence and global change.

Rene Suša is a post-doctoral fellow at the University of British Columbia. His work explores the hidden ideas, ideals, and desires that drive modern global imaginaries. He is interested in exploring educational pathways that might help us re-orient some of these desires and create openings for different (unimaginable) futures. 